Supporting Information for

\title{
Moist-Induced Electricity Generation by Electrospun Cellulose Acetate Membranes with Optimized Porous Structures
}

Quanqian Lyu, Bolun Peng, Zhanjun Xie, Shuo Du, Lianbin Zhang*, and Jintao Zhu*

State Key Laboratory of Material Processing and Die \& Mould Technology, Key Laboratory of Material Chemistry for Energy Conversion and Storage (HUST) of Ministry of Education, School of Chemistry and Chemical Engineering, Huazhong University of Science and Technology (HUST), Wuhan 430074, China.

E-mail: zhanglianbin@hust.edu.cn(L.Z.); jtzhu@mail.hust.edu.cn (J. Z.) 


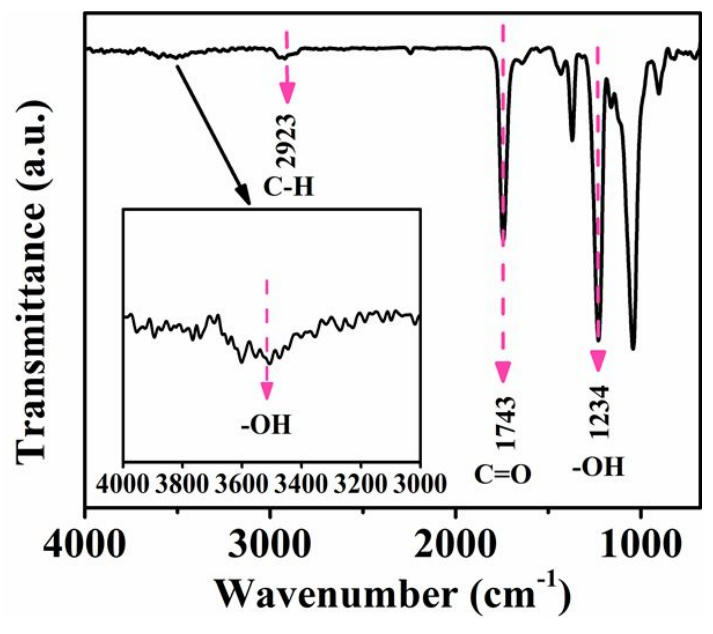

Figure S1. FTIR spectrum of the electrospun porous CA membrane. Inset: magnified spectrum in the range of $3000-4000 \mathrm{~cm}^{-1}$.
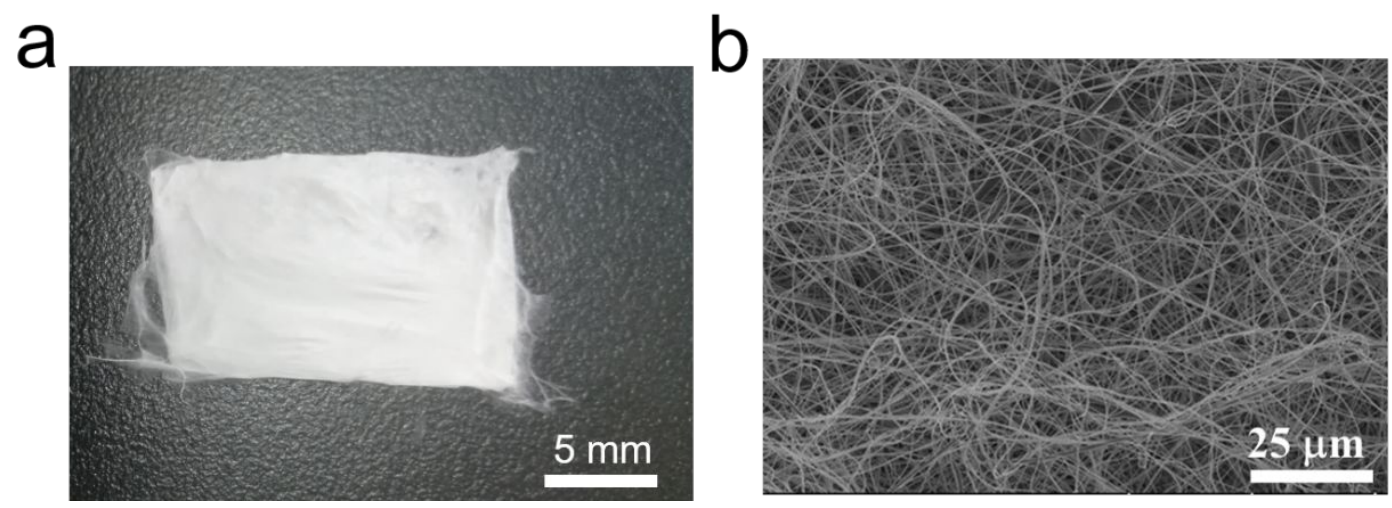

Figure S2. (a) Photograph and (b) SEM image of original electrospun CA membrane (Morg) peeled off from $\mathrm{Al}$ foil collector.
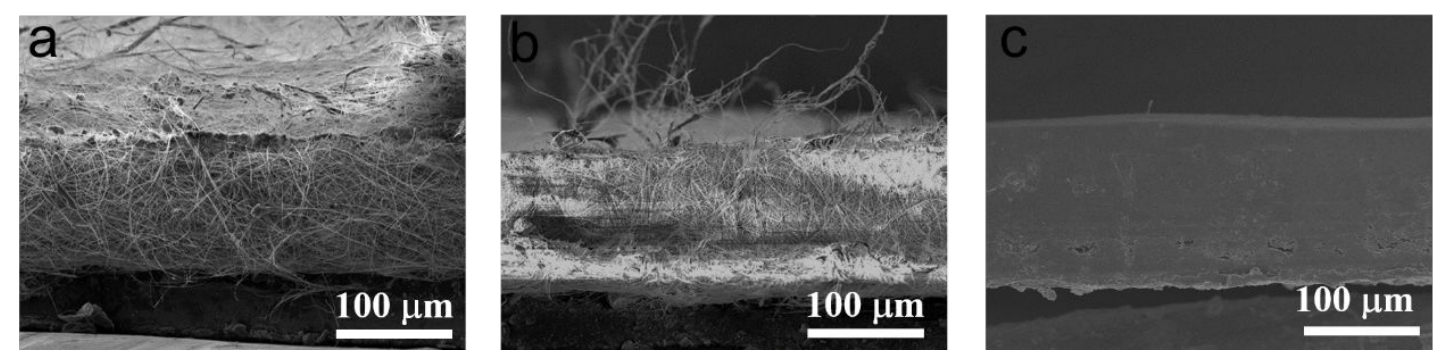

Figure S3. Cross-sectional SEM images of (a) Mcomp, (b) M5, and (c) M15. 

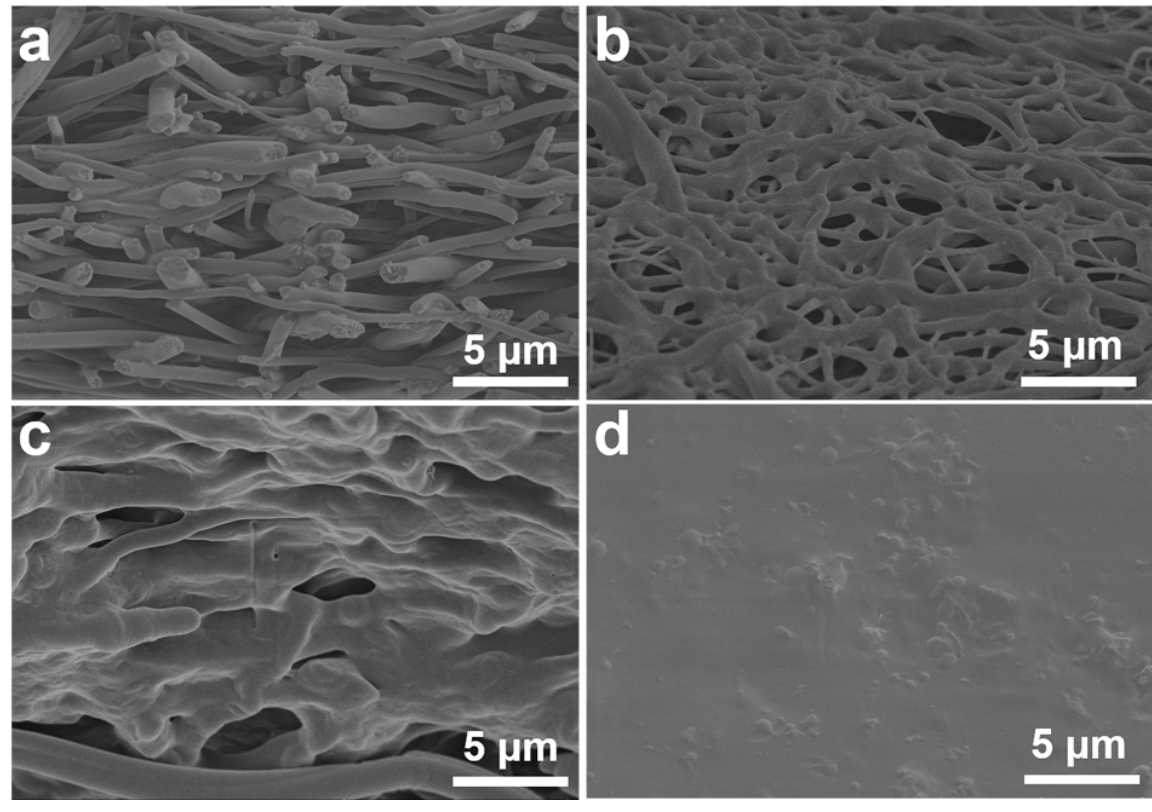

Figure S4. Cross-sectional SEM images of (a) M5, (b) M10, (c) M12, (d) M15.
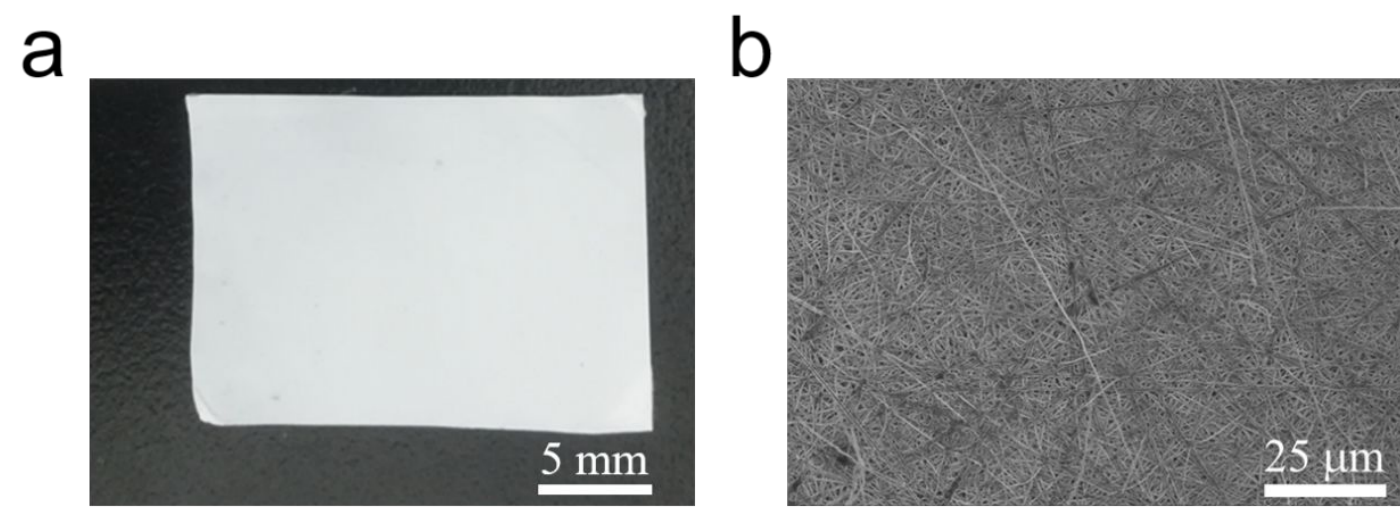

Figure S5. (a) Photograph and (b) SEM image of electrospun CA membrane (M5) after compression and annealing for $5 \mathrm{~min}$. 


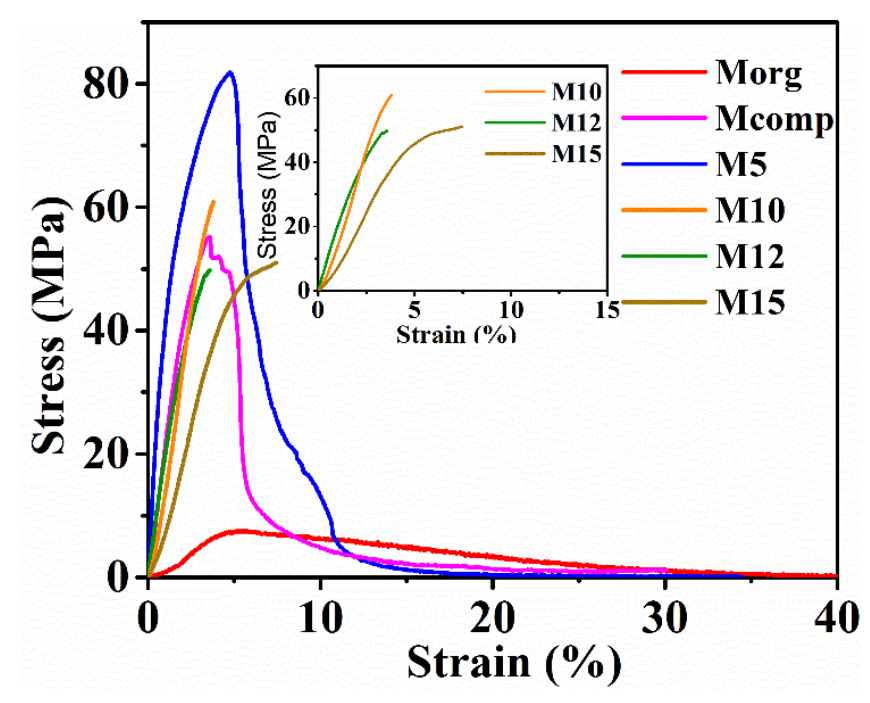

Figure S6. Stress-strain curves of CA membranes with different treatments.

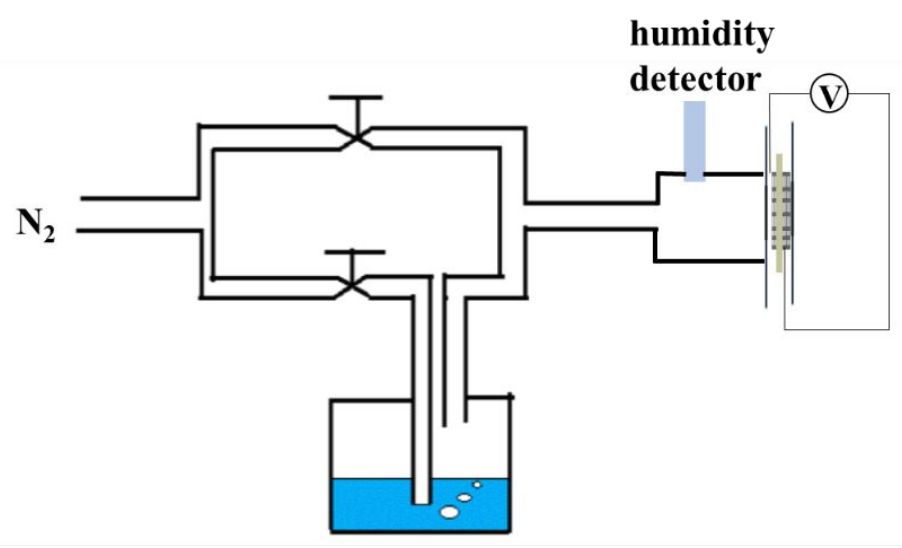

Figure S7. Schematic illustration of the lab-made setup for electricity-generation measurement of the P-CMEG with moist flows with controlled RHs. 


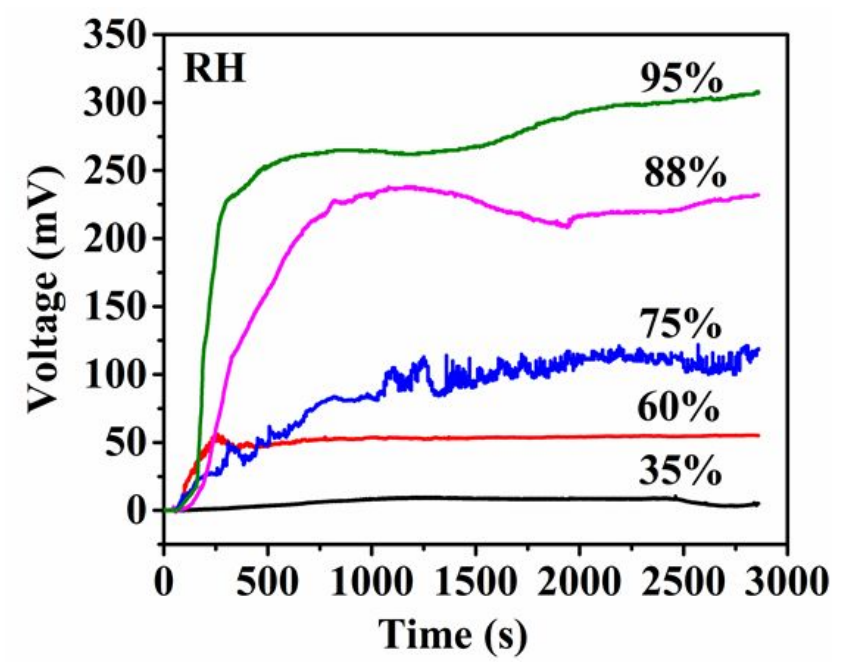

Figure S8. $\mathrm{V}_{\text {oc }}$ of P-CMEG based on M5 under different RHs at room temperature.
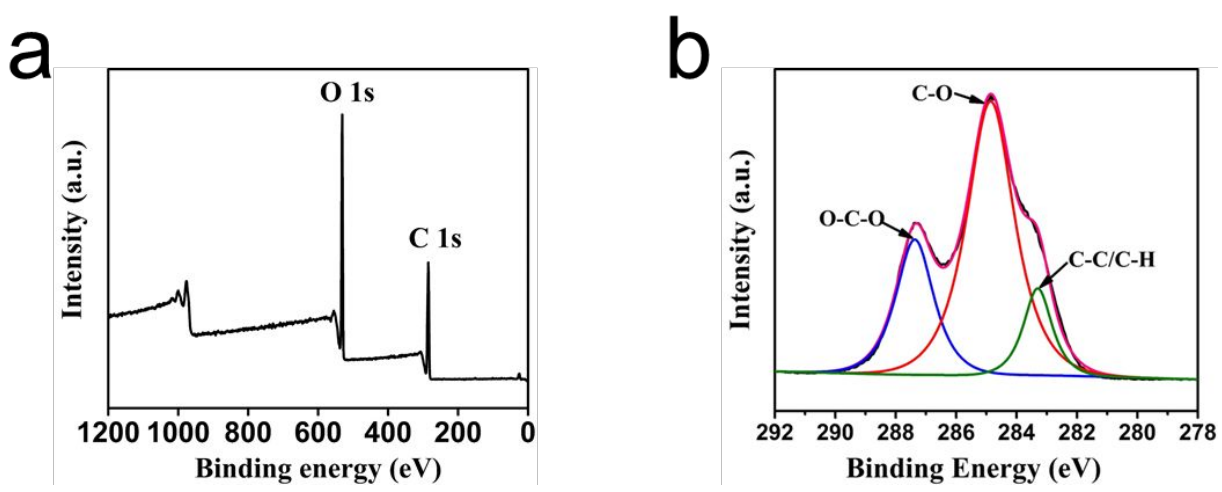

Figure S9. XPS spectra of electrospun CA nanofibrous membrane. The peaks at 284.8 $\mathrm{eV}$ and $287.4 \mathrm{eV}$ can be attributed to the $\mathrm{C}-\mathrm{O}$ bond and $\mathrm{O}-\mathrm{C}-\mathrm{O}$ bond, further proving the existence of oxygen-containing functional groups. 


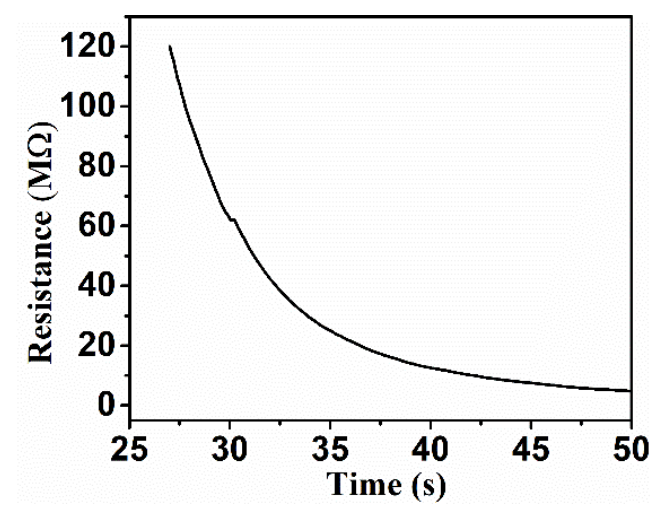

Figure S10. The change of membrane resistance with the time when being exposed to moist.

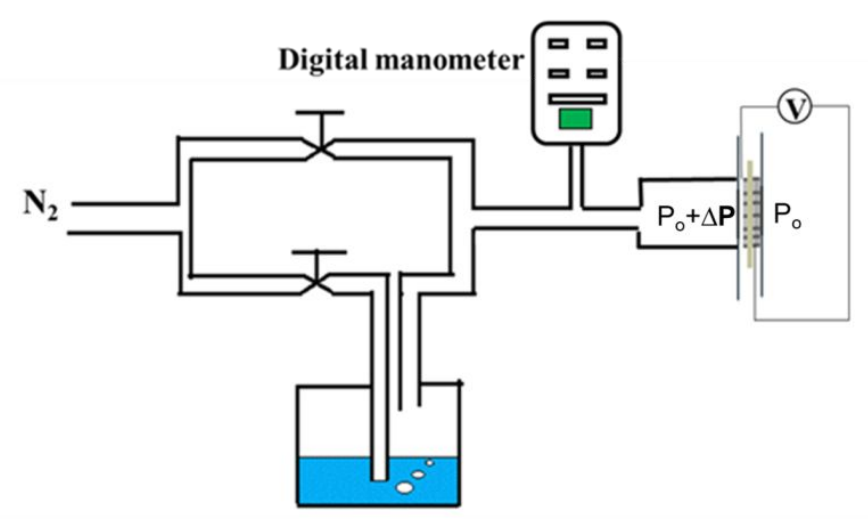

Figure S11. Schematic illustration of the lab-made setup for measurement of the transmembrane pressure with controlled flow rates. At the same flow rate $\left(2 \mathrm{~L} \mathrm{~min}^{-1}\right)$, the porous CA membranes (Morg, Mcomp, and M5) produced different transmembrane pressures. $\mathrm{P}_{0}$ is the atmospheric pressure and $\Delta \mathrm{P}$ is the transmembrane pressure drop. 

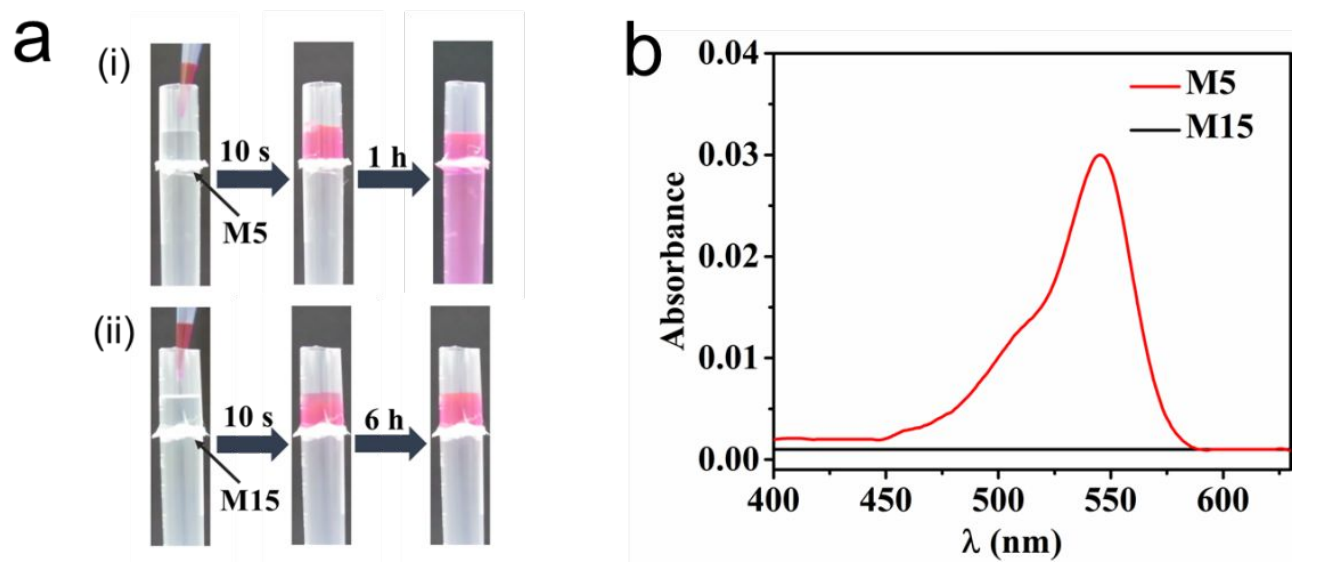

Figure S12. (a) Photographs show the dynamic color change of the solution separated by M5 and M15, respectively. (b) UV-vis absorption spectra of the aqueous solution marked in inset pictures. The CA membrane was sandwiched between two cylinders of deionized water. $50 \mu \mathrm{L}$ Rhodamine B solution was added into the upper solution.
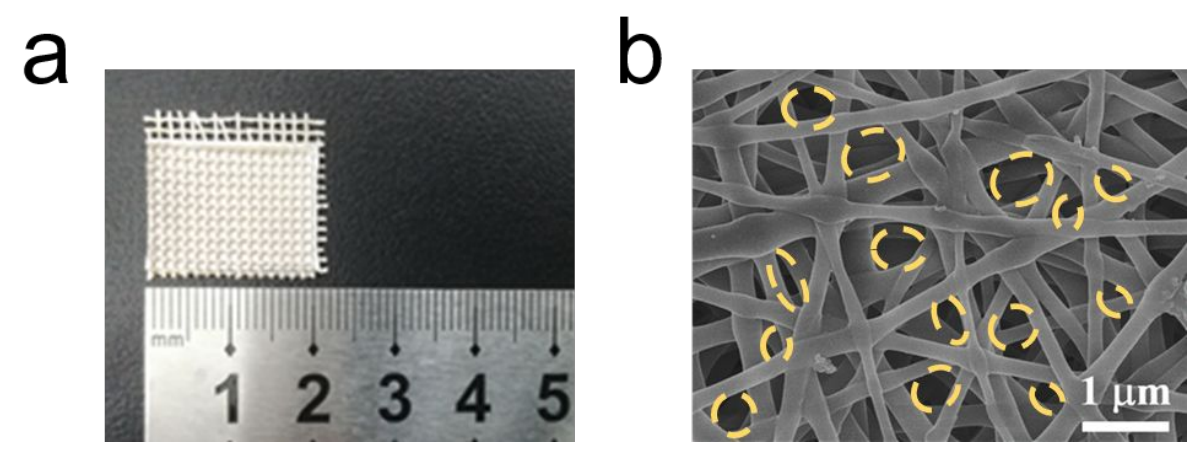

Figure S13. (a) Photograph of a P-CMEG unit based on M5 against a centimeter ruler. (b) SEM image of M5. 
Table S1. Comparison of the electricity generation performance of the CA membranes with typical reported moist-electric generators.

\begin{tabular}{|c|c|c|c|c|c|}
\hline Material & $\begin{array}{l}\text { Open circuit } \\
\text { Voltage } \\
\text { (Voc) }\end{array}$ & $\begin{array}{l}\text { Short circuit } \\
\text { current } \\
\text { (Isc) }\end{array}$ & $\begin{array}{l}\text { Output } \\
\text { power density }\end{array}$ & $\begin{array}{c}\text { Persistance } \\
\text { under } \\
\text { moisture }\end{array}$ & Reference \\
\hline \multicolumn{6}{|l|}{ Graphene } \\
\hline $\begin{array}{c}\text { oxide } \\
\text { frameworks }\end{array}$ & $260 \mathrm{mV}$ & $2.84 \mathrm{~mA}$ & / & $\sim 10 \mathrm{~s}$ & 1 \\
\hline \multicolumn{6}{|l|}{ Hygroscopic } \\
\hline $\begin{array}{c}\text { bulk graphene } \\
\text { oxide }\end{array}$ & $1500 \mathrm{mV}$ & $\sim 100 \mathrm{nA}$ & $32 \mathrm{~mW} \cdot \mathrm{cm}^{-3}$ & $>1.7 \mathrm{~h}$ & 2 \\
\hline $\begin{array}{c}\mathrm{TiO}_{2} \\
\text { nanowires }\end{array}$ & $520 \mathrm{mV}$ & $8 \mu \mathrm{A} \cdot \mathrm{cm}^{-2}$ & I & $120 \mathrm{~s}$ & 3 \\
\hline $\begin{array}{c}\text { Polypyrrole } \\
\text { nanowire }\end{array}$ & $75 \mathrm{mV}$ & $140 \mathrm{nA}$ & I & $<1 \mathrm{~s}$ & 4 \\
\hline $\begin{array}{c}\text { PSS } \\
\text { membrane }\end{array}$ & $800 \mathrm{mV}$ & $100 \mathrm{nA} \cdot \mathrm{cm}^{-2}$ & $170 \mathrm{~mW} \cdot \mathrm{m}^{-2}$ & $>1400 \mathrm{~s}$ & 5 \\
\hline GO/PAAS & $600 \mathrm{mV}$ & $12 \mu \mathrm{A} \cdot \mathrm{cm}^{-2}$ & $0.07 \mu \mathrm{W} \cdot \mathrm{cm}^{-2}$ & $>120 \mathrm{~h}$ & 6 \\
\hline $\begin{array}{l}\text { cellulose } \\
\text { nanofibrils }\end{array}$ & $110 \mathrm{mV}$ & $22 \mathrm{nA} \cdot \mathrm{cm}^{-2}$ & $0.63 \mathrm{nW} \cdot \mathrm{cm}^{-2}$ & $>167 \mathrm{~h}$ & 7 \\
\hline $\begin{array}{c}\text { protein } \\
\text { nanowires }\end{array}$ & $500 \mathrm{mV}$ & $250 \mathrm{nA}$ & $4 \mathrm{~mW} \cdot \mathrm{cm}^{-2}$ & $>20 \mathrm{~h}$ & 8 \\
\hline $\begin{array}{l}\text { asymmetric } \\
\text { cellulose }\end{array}$ & $115 \mathrm{mV}$ & $45 \mathrm{nA}$ & / & $>20 \mathrm{~h}$ & 9 \\
\hline nanofibrils & & & & & \\
\hline This work & $300 \mathrm{mV}$ & $80 \mathrm{nA} \mathrm{cm}^{-2}$ & $8.4 \mathrm{nW} \mathrm{cm}^{-2}$ & $>24 \mathrm{~h}$ & \\
\hline
\end{tabular}



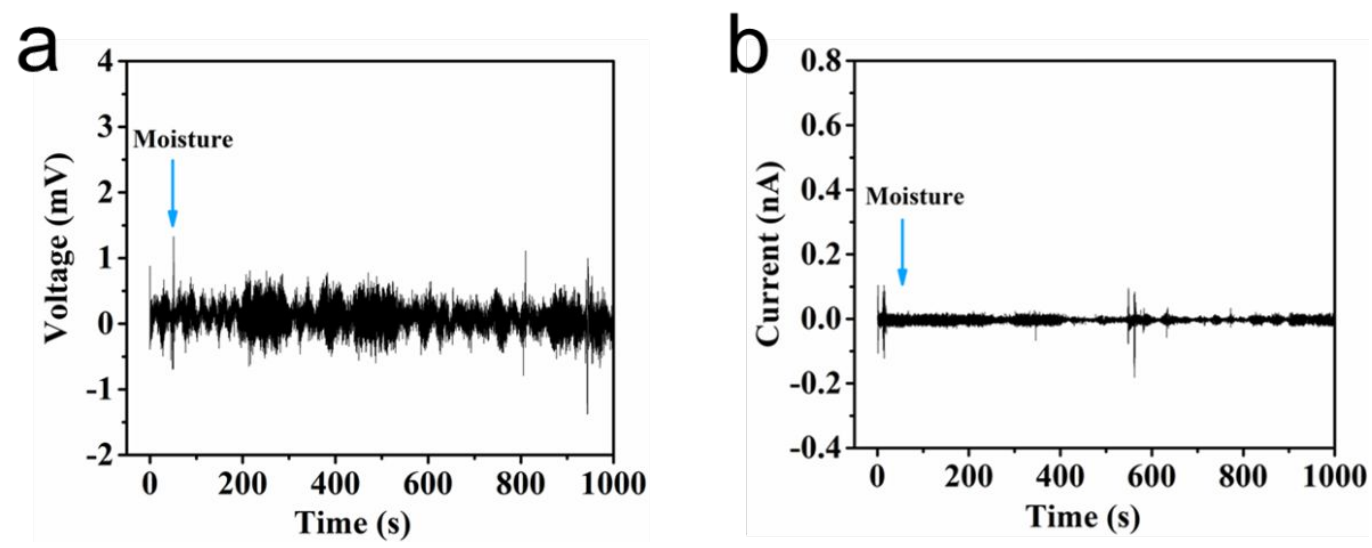

Figure S14. (a) $\mathrm{V}_{\text {oc }}$ of P-CMEG when porous $\mathrm{CA}$ membrane was removed from the device under moisture. (b) $\mathrm{I}_{\text {scc }}$ of P-CMEG when porous CA membrane was removed from the device under moisture.
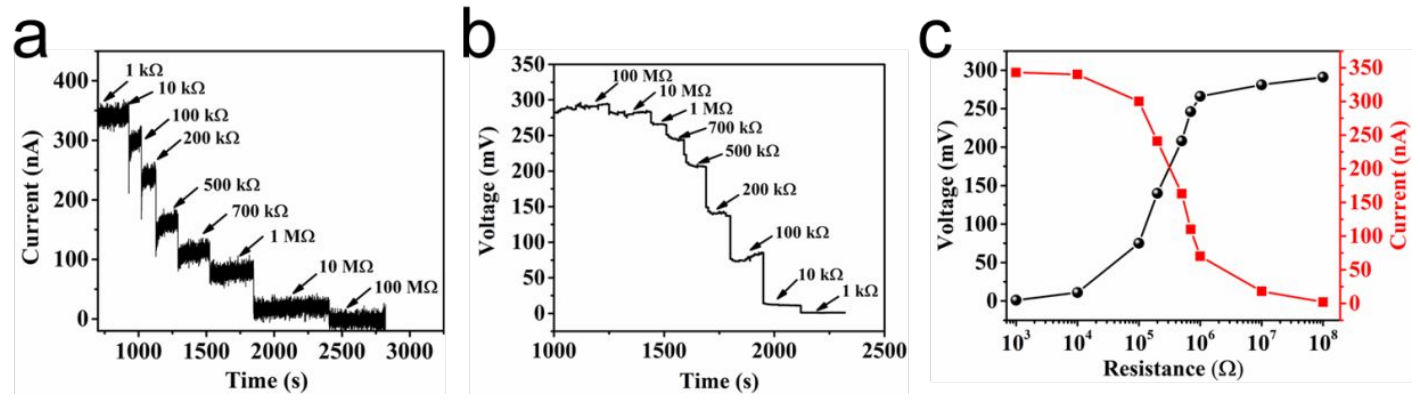

Figure S15. (a-c) Voltage and current output of a P-CMEG based on M5 membrane $\left(1.5 \times 2 \mathrm{~cm}^{2}\right)$ with different electric resistances. When the P-CMEG is connected with external loading with varied resistances (from $1 \mathrm{k} \Omega$ to $100 \mathrm{M} \Omega$ ), the short-circuit current of the system decreases from $350 \mathrm{nA}$ to $0.1 \mathrm{nA}$, the open-circuit voltage of the system increases from $1 \mathrm{mV}$ to $300 \mathrm{mV}$. 

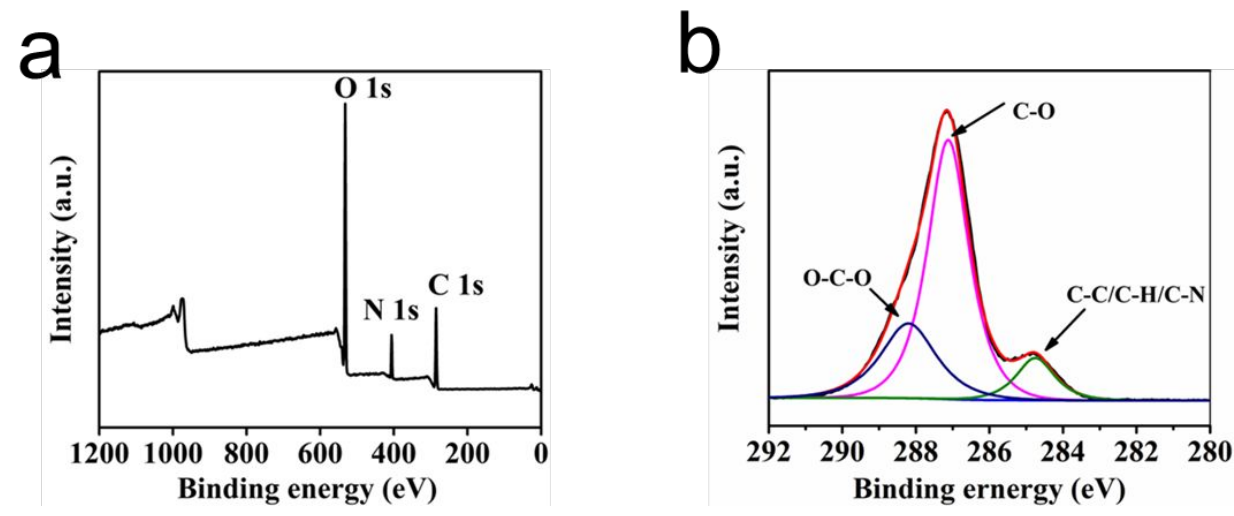

Figure S16. XPS spectra of commercial CA filter paper. The peaks at $287.1 \mathrm{eV}$ and $288.2 \mathrm{eV}$ can be attributed to the $\mathrm{C}-\mathrm{O}$ bond and $\mathrm{O}-\mathrm{C}-\mathrm{O}$ bond, proving the existence of oxygen-containing functional groups in commercial CA filter paper.

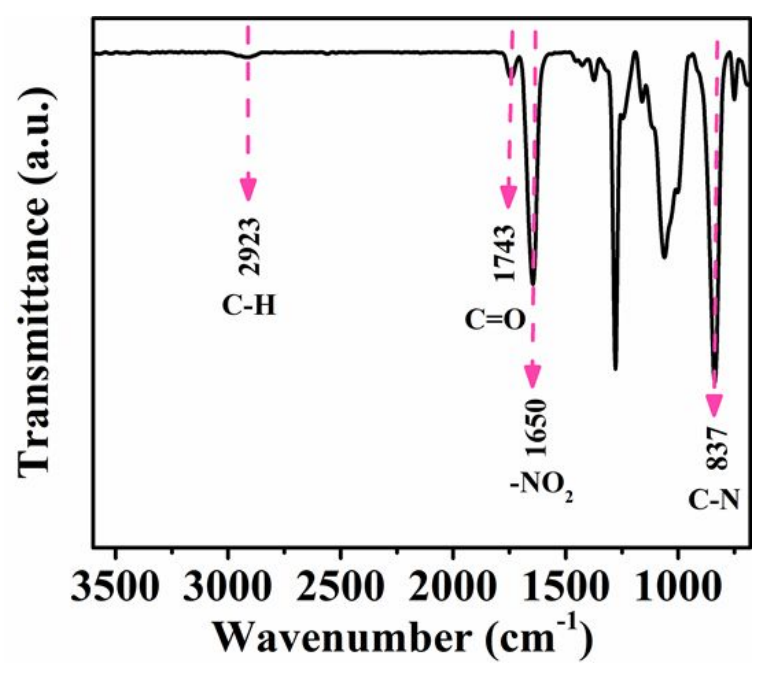

Figure S17. FTIR spectrum of commercial CA filter paper.

\section{Captions for Supplementary Movies:}

Movie S1. The working progress of the breathing sensor based on P-CMEG.

Movie S2. The calculation process of the commercial calculator powered by P-CMEGs in series. 


\section{REFERENCES}

(1) Zhao, F.; Liang, Y.; Cheng, H.; Jiang, L.; Qu, L. Highly Efficient Moisture-Enabled Electricity Generation from Graphene Oxide Frameworks. Energy Environ. Sci. 2016, 9, 912-916.

(2) Huang, Y.; Cheng, H.; Yang, C.; Zhang, P.; Liao, Q.; Yao, H.; Shi, G.; Qu, L. Interface-Mediated Hygroelectric Generator with an Output Voltage Approaching 1.5 Volts. Nat. Commun. 2018, 9, 4166.

(3) Shen, D.; Xiao, M.; Zou, G.; Liu, L.; Duley, W. W.; Zhou, Y. N. Self-Powered Wearable Electronics Based on Moisture Enabled Electricity Generation. Adv. Mater. 2018, 30, 1705925 .

(4) Nie, X.; B. Ji, B.; Chen, N.; Liang, Y.; Han, Q.; Qu, L. Gradient Doped Polymer Nanowire for Moistelectric Nanogenerator. Nano Energy 2018, 46, 297-304.

(5) Xu, T.; Ding, X.; Huang, Y.; Shao, C.; Song, L.; Gao, X.; Zhang, Z.; Qu, L. An Efficient Polymer Moist-Electric Generator. Energy Environ. Sci. 2019, 12, 972-978.

(6) Huang, Y.; Cheng, H.; Yang, C.; Yao, H.; Li, C.; Qu, L. All-Region-Applicable, Continuous Power Supply of Graphene Oxide Composite. Energy Environ. Sci. 2019, $12,1848-1856$.

(7) Li, M.; Zong, L.; Yang, W.; Li, X.; You, J.; Wu, X.; Li, Z.; Li, C. Biological Nanofibrous Generator for Electricity Harvest from Moist Air Flow. Adv. Funct. Mater. 2019, 29, 1901798.

(8) Liu, X.; Gao, H.; Ward, J. E.; Liu, X.; Yin, B.; Fu, T.; Chen, J.; Lovley, D. R.; Yao, J. Power Generation from Ambient Humidity using Protein Nanowires. Nature 2020, 
$578,550-554$.

(9) Yang, W.; Li, X.; Han, X.; Zhang, W.; Wang, Z.; Ma, X.; Li, M.; Li, C. Asymmetric Ionic Aerogel of Biologic Nanofibrils for Harvesting Electricity from Moisture. Nano Energy 2020, 71, 104670. 